\title{
An Optimization Model of the Dual-Purpose Cattle Production System in the Humid Lowlands of Venezuela
}

\author{
Charles F. Nicholson, David R. Lee, Richard N. Boisvert \\ Department of Agricultural Economics, Cornell University, Ithaca, New York \\ 14853-7801, USA
}

Robert W. Blake

Department of Animal Science, Cornell University, Ithaca, New York 14853, USA

$\&$

\author{
C. Isabella Urbina
}

Apartado 4101, San José, Costa Rica

\begin{abstract}
We developed a deterministic, multi-period linear programming (LP) model of the dual-purpose (milk-beef) cattle production system in the Sur del Lago region of Venezuela. The LP model selected animal, forage, and purchased feed activities subject to nutritional, land, and herd composition constraints to maximize discounted herd net margin. A cattle nutrition model provided original coefficients for feeds and animal nutrient requirements. Revised coefficients resulted from an iterative procedure to avoid errors from the interaction between diet and requirements. Model applications demonstrated that alternatives to traditional feeding practices are profitable and nutritionally feasible. However, the benefits of alternative nutritional management depend on labor availability. Our simulation of price policy changes in the late 1980s indicated that dual-purpose producers may experience increased relative incentives for milk production under the new input and output prices. The model is adaptable to dualpurpose production systems elsewhere in Latin America.
\end{abstract}




\section{INTRODUCTION}

The dual-purpose system has been described as 'the traditional cattle production system in the lowland tropics of Latin America in which local cattle of mixed Zebu, Criollo, and European inheritance are used for the production of milk and meat' (Seré \& de Vaccaro, 1985). The typical dual-purpose farm in Latin America is a family-owned and -operated enterprise with small capital investment located on marginal land with few alternative uses under current infrastructure and market conditions. Management practices on dual-purpose farms often lack the sophistication of specialized operations; few farmers keep formal records, uncontrolled natural mating is predominant, and hand milking is performed once daily with calves present. Notwithstanding the marginal conditions facing many dual-purpose producers, dual-purpose farms supply much of the milk produced in most of Latin America. For example, in Nicaragua, Panama, and Colombia, dual-purpose farms provided an estimated $75 \%$, $67 \%$, and $86 \%$, respectively, of national milk production in the late 1970 s and early 1980s (Seré \& de Vaccaro, 1985).

Why are dual-purpose operations so important in Latin America when specialized, intensive dairy farms are the rule in the US and Europe? A combination of climatic, nutritional, and economic constraints severely restricts the efficiency of specialized, intensive production of milk in tropical ecozones. Many Latin American countries have relatively small highland areas that are better suited to intensive milk production. However, these highland areas typically provide greater net returns when dedicated to agricultural enterprises other than livestock. Milk production in the highland areas of Latin America has remained important, but milk and beef production are increasingly located in tropical lowland areas.

Despite the significant contributions of dual-purpose farms to meeting the milk and beef demands of Latin American countries, few empirical studies or models of the dual-purpose system exist. Problems that require more detailed study include meeting nutritional requirements for dualpurpose animals, the optimal mix of milk and beef production, the allocation of seasonally variable pasture production among milking, growing, and beef animals, and the allocation of milk as an intermediate input to calves (which generates long-term benefits) versus its sale as a final product (which generates short-term financial benefits). Assessing the impacts of changes in government policies on the production and profitability of dual-purpose farms is also an important area of study, because structural changes and sectoral reforms in the 1980s have transformed the policy environment for agriculture throughout Latin America.

Previous studies of the dual-purpose system have focused on the key role 
of nutritional factors in limiting productivity and profitability (Franco, 1987; Townsend et al., 1990). Our objectives were to develop a more detailed optimization model of the dual-purpose production system in the humid lowlands of western Venezuela and to use it to evaluate alterative nutritional management strategies, to simulate the impacts of alternative farm resource availabilities, and to assess changes in production and profitability resulting from large changes in output prices and input costs.

\section{AN OPTIMIZATION MODEL OF DUAL-PURPOSE CATTLE PRODUCTION}

Our model is a deterministic, multi-period linear programming (LP) model of a representative dual-purpose farm in the Sur del Lago region of western Venezuela. The dual-purpose herds we studied in western Venezuela contrast in some ways with the generic description of dualpurpose farms elsewhere in Latin America. In general, farms in this region were larger, devoted more effort to managing nutrition and reproduction,

TABLE 1

Characteristics of Dual Purpose Farms: Sur del Lago (Venezuela) Farms and Other Regions of Latin America

\begin{tabular}{lcc}
\hline \multicolumn{1}{c}{ Characteristic } & $\begin{array}{c}\text { Sur del Lago } \\
(\mathrm{N}=22)^{a}\end{array}$ & $\begin{array}{c}\text { Other Latin }^{a} \\
\text { America }^{b}\end{array}$ \\
\hline Owner-operators, \% & 41 & $60-100$ \\
Farms hiring labor, \% & 100 & $71-93$ \\
Total area, ha & 367 & $17-219$ \\
Cows per farm & 261 & $53-97$ \\
Farms using fertilizer, \% & 59 & $8-50$ \\
Farms using any energy & & $10-73$ \\
$\quad$ or protein supplement, \% & 77 & $31-36$ \\
Age at first calving, months & 36 & $52-81$ \\
$\quad$ in herd per year & & \\
Marketable milk yield, $\quad$ kg/cow-per day & 71 & $2-6$ \\
$\quad$ Lactation length, days & 7 & $244-304$ \\
Stocking rate, AU $/$ ha & 274 & $0.8-1.9$ \\
\hline
\end{tabular}

${ }^{a}$ Sample means from Holmann (1989) survey data.

${ }^{b}$ Range of values reported by Seré \& de Vaccaro (1985) for Honduras, Costa Rica, Panamá, Bolivia, Colombia, Brazil, and Venezuela.

${ }^{c}$ Animal units. Calculated using 1.0 units for cows and steers 3-4 years, 0.6 units for heifers and steers 1-2 years, and 0.9 units for heifers and steers $2-3$ years. 
and employed more hired labor (Table 1). We selected 22 Sur del Lago farms of 157 total farms surveyed by Holmann (1989) in 1987 and 1988 as the basis for the programming model. These farms were more representative of dual-purpose farms elsewhere in Latin America because they practised hand milking, owned cows with no more than $50 \%$ Holstein germplasm, and raised male calves to marketable weights on the farm.

Linear programming techniques have frequently been used to assess nutritional aspects of tropical cattle production systems (GutierrezAlemán et al., 1986; Franco, 1987; Teitzel, 1991). We emphasized modeling nutritional characteristics of the system based on evidence that nutrition often represents the principal limitation to increased system productivity and profit. Rather than use feed and animal nutrient requirements developed for temperate climates, we developed feed and animal parameters more specific to Sur del Lago conditions. In contrast to most other studies, we accounted for variation in feed nutritive values and animal requirements due to diet composition.

The LP model represents a 3-year cow replacement cycle in six periods. Each year is divided into a 9-month rainy season and a 3-month dry season to account for variation in forage quality and availability. The model simultaneously allocates farm forage and purchased feed resources among calves, heifers, steers, and lactating and dry cows. The structure of the model, although specific to the system in the Sur del Lago, is adaptable to dual-purpose systems elsewhere in Latin America.

\section{Model objective function}

The LP model maximizes discounted herd net margin (total revenues from milk and animal sales less variable costs for feed, labor, animal health, and reproduction). Net margin was discounted to account for the opportunity costs of resources used in dual-purpose production. We treated farm assets other than cattle (land, buildings, equipment, etc.) as predetermined over the 3-year model horizon; costs associated with farm assets are treated as fixed (sunk) costs. Overhead costs are thus omitted from the objective function.

\section{Model activities}

The LP model includes four categories of activities: animal inventory, feed and nutrition, other farm inputs, and farm outputs. Animal inventory activities (the number of animals in a period) are specified for 10 age-sex groups (Table 2). Three animal inventory activities per period represent the negative and positive energy balances for cows during 
TABLE 2

LP Model Activities and Constraints

\begin{tabular}{ll}
\hline \multicolumn{1}{c}{ Activity } & \multicolumn{1}{c}{ Constraint } \\
\hline Animal groups & Nutritional \\
Lactating cows, negative ME balance & Metabolizable energy requirements \\
Lactating cows, positive ME balance & Metabolizable protein requirements \\
Dry cows, positive ME balance & NDF intake capacity \\
Calves, 0-1 year & Dry matter intake capacity \\
Heifers, 1-2 years & Minimum NDF in diet \\
Heifers, 2-3 years & Nitrogen content of alternative feed mixtures \\
Steers, 1-2 years & Tissue mobilization and repletion transfers \\
Steers, 2-3 years & \\
Steers, 3-4 years & Farm resource \\
& Total land \\
Feed and nutrition & Land in water-tolerant grass species \\
Forage production: & Total supplementation capacity \\
Fertilized grasses on drained soils & \\
Fertilized grasses on wet soil & Herd structure \\
Unfertilized grasses on drained soils & Cow numbers constant ${ }^{a}$ \\
Unfertilized grasses on wet soils & Calf number relation to cow numbers \\
Purchased feeds: & Transfers for calves, heifers, steers \\
Commercial concentrate & Cows culled \\
Molasses & Replacement heifers \\
Urea & Animal sales \\
Cassava root & \\
Tissue mobilization and repletion: & Resource balance (summing) \\
Adipose tissue & Fertilizer \\
Protein tissue & Herbicide \\
Other inputs & Hired labor \\
Hired labor & \\
Fertilizer & \\
Herbicide & \\
Outputs & \\
Milk sales & \\
Animal sales (by animal group) & \\
\hline & \\
\hline
\end{tabular}

${ }^{a}$ Cow numbers are assumed constant for all model periods, but the number of cows is determined by the LP model.

lactation and post-lactation. Seven animal inventory activities per period for calves, heifers, and steers are specified based on animal age. Herd size and composition are thus determined by the model.

Feed and nutritional activities comprise forage production, purchases of supplemental feeds, and mobilization and repletion of body tissues by cows (Table 2). Forage production activities allow the model to select the optimal combination of fertilized and unfertilized grasses on a fixed allocation of well-drained and wet soils. Supplemental feed activities 
included commercial concentrate commonly used on dual-purpose farms in the Sur del Lago in 1987 and 1988, as well as locally available supplements such as molasses, urea, and cassava root (referred to subsequently as 'alternative' feeds). Mobilization and repletion of adipose and protein tissues by cows are included because the dynamics of body tissue are a physiological reality in some tropical situations (Neidhardt et al., 1979), and because Reyes et al. (1981) found that management of body tissue dynamics could improve farm profitability.

Other farm input activities include hired labor for animal care and pasture maintenance (separated into milking and managerial/seasonal labor based on wage rates), and fertilizer and herbicide for forage production. Milk and animal sales activities, the latter specified for each of the animal groups, permit the model to determine the optimal combination of milk and beef output.

Although Holmann (1989) surveyed farms without crop enterprises to simplify the assessment of livestock enterprises, cropping is typically unimportant on dual-purpose farms in the Sur del Lago region. Therefore, no cropping activities are included in the LP model. No activities are specified for operating loans or other farm credit because a prototype model indicated that such activities would not form part of the optimal solutions.

\section{Model constraints}

The LP model includes constraints on animal nutrition, farm resources, herd structure, and resource balances (Table 2). The nutritional and herd structure constraints employed here have not been used in previous studies of dual-purpose cattle systems but are key determinants of model outcomes (and are outlined in detail in Appendix 1). Nutritional constraints require that optimal diets satisfy animal requirements for energy and protein subject to restrictions on intakes of neutral detergent fiber (NDF) and dry matter (DM). In addition, constraints specify a minimum proportion of NDF in the diet from forage sources in diets for cows, heifers, and calves. The protein content of supplemental 'alternative' feeds is constrained to avoid depletion of rumen nitrogen. Constraints on tissue mobilization and repletion ensure that adipose and protein body tissues mobilized by cows during early lactation are repleted prior to the next parturition.

Herd composition constraints permit the model to select the optimal combination of animal inventory and animal sales consistent with extant patterns of cattle reproduction (Appendix 1). Although cow numbers are assumed constant for all model periods, the optimal number of cows is determined by the LP model. Calf numbers, cows culled, and replace- 
ment heifers are related to cow numbers. Transfer and animal sales constraints together maintain appropriate relationships among numbers of calves, heifers, and steers for the six model periods; these constraints are based on herd reproductive performance and optimal animal sales.

Farm resource constraints include total pasture area (350 ha), land area sown in water-tolerant species $(40 \%$ of the total; areas of many dual-purpose farms in the Sur del Lago are subject to seasonal flooding), and capacity of the farm to use supplemental feeds.

\section{DEVELOPMENT OF MODEL TECHNICAL COEFFICIENTS}

Survey data from Holmann (1989) provided many of the technical coefficients on input and output prices, herd management practices, herd productivity and reproductive characteristics, and labor requirements. Animal growth, forage yield and composition, and tissue dynamics coefficients were from the agronomy and animal nutrition literature. A summary of assumptions, sources, and methods for selected technical coefficients is presented in Appendix 2; the complete discussion of LP technical coefficients is found in Nicholson (1990). However, our development of feed and animal technical coefficients merits further discussion here.

\section{Feed and animal technical coefficients}

Empirical relationships developed in temperate climates for feed nutritive values, feed intakes, and metabolic efficiencies often are employed to predict nutritional outcomes and performance for tropical cattle. Differences in feed quality, feeding practices, breed-related factors, and environmental conditions between temperate and tropical regions, however, can cause temperate relationships to predict animal performance inaccurately in tropical settings (Van Soest, 1987). Thus, we viewed the development of feed nutritive values and animal nutritive requirements better characterizing the Sur del Lago production environment as a necessary precursor to development of the LP model.

Accordingly, we adapted the Cornell Net Carbohydrate and Protein System (CNCPS) to estimate feed nutritive values and animal nutrient requirements for the Sur del Lago production system. The CNCPS is a cattle nutritional simulation model that estimates metabolizable energy and protein available from feeds; separate CNCPS sub-models of maintenance, growth, lactation and gestation predict animal performance. The CNCPS had previously been validated for temperate dairy and cowcalf production (Fox et al., 1992; Russell et al., 1992; Sniffen et al., 1992). 
The CNCPS requires more detailed animal and feed characteristics than other predictive systems (e.g. Kearl, 1982; National Research Council, 1988) and it can more readily account for differences in animal and feed characteristics between temperate and tropical settings. To adapt the CNCPS, we developed and modified animal and feed information for the Sur del Lago based on literature from Venezuela and other areas in tropical Latin America. Adaptation of the CNCPS model is described in detail in Nicholson et al. (in press).

Predicted metabolizable energy (ME) values for commercial concentrate, molasses, urea, cassava and two tropical grasses ranged from 7.8 to $12.49 \mathrm{MJ} / \mathrm{kg}$ dry matter (DM), and predicted metabolizable protein (MP) values were between 91 and $179 \mathrm{~g} / \mathrm{kg}$ DM (see Table 3, which also includes

TABLE 3

Nutritive Values ${ }^{a}$ and Costs per Unit of Forages and Feeds Used in the LP Model

\begin{tabular}{|c|c|c|c|c|c|}
\hline \multirow{2}{*}{ Forage or feed } & \multirow{2}{*}{$\begin{array}{c}\text { Yield } \\
\text { (MT DM } \\
\text { per ha per } \\
\text { year) }\end{array}$} & \multirow{2}{*}{$\begin{array}{c}M E^{b} \\
(M J / k g D M)\end{array}$} & \multirow{2}{*}{$\begin{array}{c}M P^{c} \\
(g / k g D M)\end{array}$} & \multicolumn{2}{|c|}{ Cost per unit } \\
\hline & & & & $\begin{array}{c}M E^{b} \\
(\$ / G J)\end{array}$ & $\begin{array}{c}M P^{c} \\
(\$ / k g)\end{array}$ \\
\hline \multicolumn{6}{|l|}{ Forage, fertilized } \\
\hline Drained soils ${ }^{d}$ & $8 \cdot 24$ & $8 \cdot 38$ & 98 & $5 \cdot 25$ & 0.045 \\
\hline Wet soils ${ }^{e}$ & $10 \cdot 39$ & $7 \cdot 88$ & 91 & $4 \cdot 30$ & 0.038 \\
\hline \multicolumn{6}{|l|}{ Forage, unfertilized } \\
\hline Drained soils $^{d}$ & $7 \cdot 11$ & 8.09 & 92 & $5 \cdot 01$ & 0.044 \\
\hline Wet soils ${ }^{e}$ & $9 \cdot 27$ & $7 \cdot 79$ & 88 & 4.06 & 0.039 \\
\hline Commercial concentrate & & $10 \cdot 60$ & 132 & $8 \cdot 11$ & 0.661 \\
\hline Molasses & & 11.90 & 161 & $5 \cdot 01$ & 0.373 \\
\hline Cassava & & 12.49 & 179 & $7 \cdot 88$ & 0.553 \\
\hline Milk $^{f}$ & & $21 \cdot 32$ & 270 & 44.87 & $3 \cdot 540$ \\
\hline
\end{tabular}

${ }^{a}$ Nutritive values predicted with the Cornell Net Carbohydrate and Protein System (CNCPS).

${ }^{b} \mathrm{ME}=$ metabolizable energy.

${ }^{c} \mathrm{MP}=$ metabolizable protein. MP values calculated using the mean MP/CP ratio for all animal classes. The CNCPS predicts MP values based on energy available for microbial growth, assuming sufficient rumen N. High energy, low protein feeds such as cassava have high MP values because their energy content supports microbial growth.

${ }^{d}$ Combination of Panicum maximum and Cynodon nlemfuensis. Passage rates of $6 \% / \mathrm{h}$ were assumed. Digestion rates of the available NDF fraction were assumed to be $5.5 \% / \mathrm{h}$ when rumen nitrogen was not limiting.

${ }^{e}$ Combination of Echinochloa polystachya and Brachiaria mutica. Passage rates of $6 \% / \mathrm{h}$ were assumed. Digestion rates of the available NDF fraction were assumed to be $5.5 \% / \mathrm{h}$ when rumen nitrogen was not limiting.

${ }^{f}$ Milk consumed by calves, which is $60 \%$ residual milk and $40 \%$ normal milk. Residual milk is milk left in the udder after milking. 
TABLE 4

Average Daily Dry Matter Intake, Metabolizable Energy Requirements, and Metabolizable Protein Requirements Predicted by the CNCPS, by Animal Class

\begin{tabular}{|c|c|c|c|c|}
\hline Animal class & $\begin{array}{l}B W^{a} \\
(k g)\end{array}$ & $\begin{array}{c}D M I^{b} \\
(k g / d a y)\end{array}$ & $\begin{array}{c}M E R^{c} \\
(M J / d a y)\end{array}$ & $\begin{array}{c}M P R^{d} \\
\text { (g/day) }\end{array}$ \\
\hline $\begin{array}{l}\text { Lactating cow, } \\
1-90 \text { days in milk }\end{array}$ & 450 & $11 \cdot 5$ & 114.8 & 1312 \\
\hline $\begin{array}{l}\text { Lactating cow, } \\
91-270 \text { days in milk }\end{array}$ & 450 & $12 \cdot 3$ & $96 \cdot 0$ & 1121 \\
\hline $\begin{array}{l}\text { Dry gestating cow, } \\
271-420 \text { days in milk }\end{array}$ & 450 & 9.7 & 62.0 & 592 \\
\hline Female calf, $0-1$ year & 132 & 3.9 & $36 \cdot 5$ & 359 \\
\hline Male calf, $0-1$ year & 145 & $4 \cdot 1$ & $38 \cdot 1$ & 390 \\
\hline Heifer, 1-2 year & 291 & $7 \cdot 3$ & $59 \cdot 1$ & 476 \\
\hline Heifer, 2-3 year & 368 & $7 \cdot 6$ & $62 \cdot 0$ & 528 \\
\hline Steer, 1-2 year & 324 & 7.9 & $63 \cdot 7$ & 526 \\
\hline Steer, 2-3 year & 415 & 7.9 & $63 \cdot 7$ & 480 \\
\hline Steer, 3-4 year & 477 & $8 \cdot 5$ & $69 \cdot 1$ & 506 \\
\hline
\end{tabular}

${ }^{a}$ Mature body weight for cows and average yearly body weight for other animal groups.

${ }^{b}$ Dry matter intake for lactating cows predicted based on Reid et al. (1988) relationship for NDF intake per kg metabolic body weight and Williams et al. (1989) intake pattern during lactation. DM intake for other animal classes is CNCPS prediction to achieve animal growth.

${ }^{c}$ Average final ME requirements.

${ }^{d}$ Average final MP requirements.

assumed forage yields and costs per unit ME and MP). We developed intake limits for NDF and DM for crossbred animals by integrating empirical relationships from Reid et al. (1988) and Williams et al. (1989) (see nutritional assumptions in Appendix 2). Requirements for ME and MP per period for all animal groups are presented in Table 4, which also contains assumed animal weights and DM intake. However, animal requirements used in the LP model varied depending on diet composition using an iterative procedure described below.

\section{ITERATIVE PROCEDURE FOR EVALUATING CATTLE DIETS}

Animal nutrient requirements and the nutritive value of forages and feeds vary depending on the composition of the diet, environmental conditions, and animal characteristics (Fox et al., 1992). Variation in feed nutritive values and animal nutrient requirements with diet composition is particularly troublesome in a linear programming formulation because 
it implies violation of the standard assumption of invariant nutritional coefficients for the LP matrix. Accordingly, we used an iterative procedure between the CNCPS and the LP model to ensure that optimal diets were consistent with the animal nutrient requirements and feed nutritive values used to generate them.

Initial nutrient requirements and nutritive values were determined with the CNCPS, then were modified based on the optimal diet composition selected by the LP model for each group of animals (Fig. 1). We repeated this procedure until diet composition (hence nutritive values and nutrient requirements) predicted by the LP model changed little from one iteration to the next. For most versions of the model, this occurred after three iterations. The iterative procedure allowed the LP model to account for variations in feed nutritive values with changes in diet composition of up to $5 \%$, and variations in animal nutrient requirements of $3 \%$.

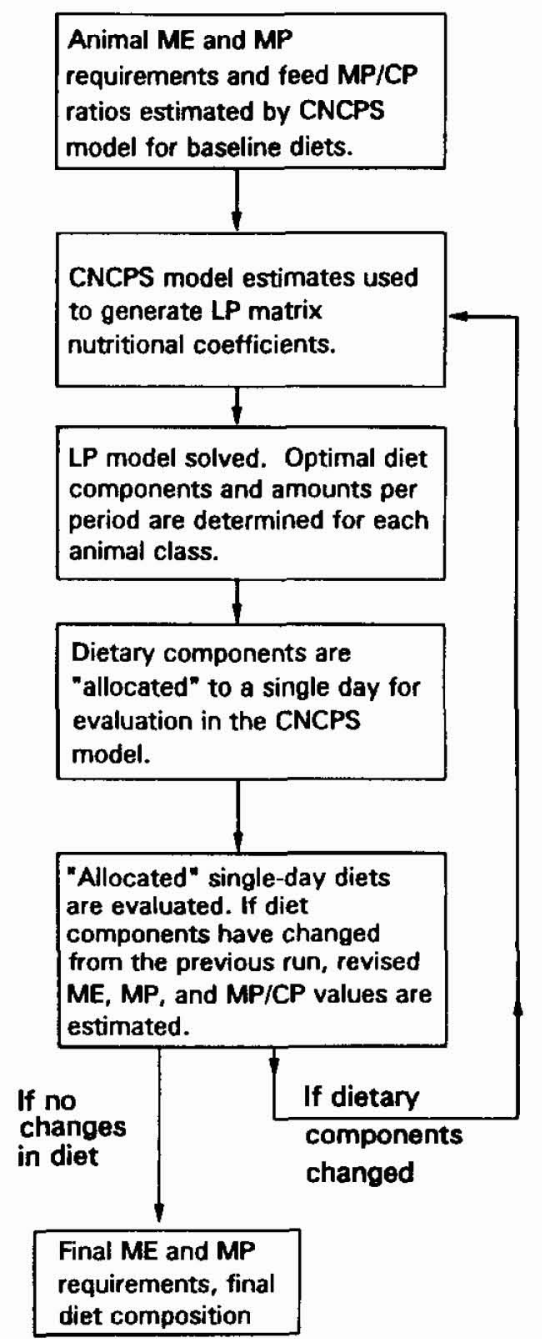

Fig. 1. Iterative procedure for evaluating cattle diets predicted by the LP model. 


\section{MODEL SCENARIOS AND VALIDATION}

\section{Model scenarios}

We developed a number of versions of the LP model to assess different nutritional management strategies, resource availabilities, and input-output price scenarios. In this paper, we refer to results from a baseline (B) model simulating the use of commercial concentrate consistent with common practice in the Sur del Lago in the late 1980s ( $2 \mathrm{~kg}$ concentrate per lactating cow per day regardless of production or days in milk). We also discuss three variations of a model formulation permitting use of concentrate and other supplemental feeds (molasses, urea, and cassava), termed the Alternative Feeds formulation (AF). Modifications of the AF formulation permitted us to emphasize the impacts of restricting labor availability and changing input and output prices on the profitability of dual-purpose farms.

The relationships between labor availability, farm productivity, and profit are important because most labor on dual-purpose farms in the Sur del Lago is hired. Turnover rates as high as $80 \%$ per year have been reported (Holmann, 1989), and farm managers hired by absentee owners often maintain extra laborers to protect themselves from turnover, worker absences, and injuries. The widespread use of commercial concentrate may also reflect managers' desires to minimize the number of laborers in light of the difficulties in retaining workers (J. Afonso, personal communication). Consequently, we modified the AF model formulation to develop a restricted labor model formulation (RL) that limited total hired workers to the mean for the 22 farms in our sample, that is, 12 milking workers.

Dramatic changes in the prices of inputs and outputs faced by dualpurpose producers occurred from 1987 to 1989 because of changes in government price policy (Table 5). During this period, for example, fertilizer subsidies were reduced and devaluation of the official exchange rate more than doubled the cost of commercial concentrate. Partly to offset these cost increases, the government-controlled producer price of milk was increased $84 \%$. To assess the impacts of these policy changes, we modified the AF model to examine the effects of changing prices on optimal resource use and net margins to producers in a formulation designated the Price Policy Changes (PPC) model.

\section{Model validation}

McCarl \& Apland (1986) propose a formal process to validate programming models. Their process includes validation by construct (use of 
TABLE 5

Changes in Prices of Selected Inputs and Outputs from 1987-88 to mid-1989 Assumed in the Price Policy Changes LP Model Formulation

\begin{tabular}{|c|c|c|c|c|}
\hline \multirow[t]{2}{*}{ Input or output } & \multirow[t]{2}{*}{ Units } & \multicolumn{2}{|c|}{ Price/unit $\left(B s^{a}\right)$} & \multirow{2}{*}{$\begin{array}{c}\text { Percentage } \\
\text { increase }\end{array}$} \\
\hline & & $1987-88$ & mid-1989 & \\
\hline \multicolumn{5}{|l|}{ Inputs } \\
\hline Commercial concentrate & $\mathrm{kg}$ & $2 \cdot 35$ & $6 \cdot 75$ & 187 \\
\hline Molasses & $\mathrm{kg}$ & $1 \cdot 34$ & $3 \cdot 40$ & 154 \\
\hline Urea & $\mathrm{kg}$ & 0.66 & $2 \cdot 55$ & 286 \\
\hline Cassava & $\mathrm{kg}$ & $1 \cdot 04$ & 1.82 & 75 \\
\hline Herbicide & liter & $80 \cdot 00$ & $216 \cdot 84$ & 171 \\
\hline Fertilizer & $\mathrm{kg}$ & 0.66 & 1.00 & 52 \\
\hline \multicolumn{5}{|l|}{ Outputs } \\
\hline Milk & liter & $4 \cdot 90$ & 9.00 & 84 \\
\hline Steer, $1-3$ years & $\mathrm{kg} \mathrm{LW}^{b}$ & $20 \cdot 00$ & 26.00 & 30 \\
\hline Steer, $3-4$ years & $\mathrm{kg} \mathrm{LW}^{b}$ & $18 \cdot 50$ & 24.00 & 30 \\
\hline Cull cow & $\mathrm{kg} \mathrm{LW}^{b}$ & $16 \cdot 00$ & $20 \cdot 00$ & 25 \\
\hline
\end{tabular}

${ }^{a}$ Bolivares, the Venezuelan currency. In $1987-88,30$ Bs equalled \$1 US.

${ }^{b}$ Kilograms live weight.

a priori information to assure representative solutions) and by results (experiments to test the robustness of model solutions). Our validation procedure relied heavily on validation by construct, that is, we sought to develop a model structure and technical coefficients consistent with the underlying processes of the dual-purpose production system.

To assess the representativeness of our model structure and technical coefficients, we compared LP model predictions for two key productivity measures, stocking rate (animal units/ha) and milk produced per ha per year, with their mean and variation for the 22 Sur del Lago farms (Table 6). Stocking rates predicted by all four LP models are within the range observed for the 22 farms. Milk production per ha per year exhibits a similar pattern. Stocking rates and milk per ha predicted by the B, AF, and PPC model formulations lie within the highest quintile of survey farms for these measures, and thus appear more representative of highproductivity Sur del Lago farms. The RL formulation yields predictions in the lowest quintile of these measures, and thus appears more representative of lower productivity farms. Because the LP models predicted farm productivity consistent with the range exhibited by the 22 farms surveyed, we concluded that model solutions were reasonably representative of the dual-purpose system. 
TABLE 6

Model Representativeness: Productivity Parameters from Farm Survey Data and LP Model Formulations

\begin{tabular}{|c|c|c|c|c|c|c|c|}
\hline \multirow{3}{*}{$\begin{array}{l}\text { Productivity } \\
\text { measure }\end{array}$} & \multirow{2}{*}{\multicolumn{3}{|c|}{$\begin{array}{l}\text { Farm survey data } \\
\qquad(N=22)\end{array}$}} & \multicolumn{3}{|c|}{ LP model formulation } & \multirow{3}{*}{$\begin{array}{c}\text { Price } \\
\text { policy } \\
\text { changes }\end{array}$} \\
\hline & & & & & & Restricted & \\
\hline & Mean & $S D$ & Range & line & feeds & labor & \\
\hline \multicolumn{8}{|l|}{ Stocking rate ${ }^{a}$} \\
\hline $\mathrm{AU}^{b} / \mathrm{ha}$ & 1.64 & $0 \cdot 70$ & $0.86-4.07$ & $2 \cdot 33$ & $2 \cdot 64$ & 1.02 & $2 \cdot 38$ \\
\hline \multicolumn{8}{|l|}{ Milk production/ha ${ }^{a}$} \\
\hline liters/year & 1354 & 558 & $338-2571$ & 2138 & 2357 & 727 & 2224 \\
\hline
\end{tabular}

${ }^{a}$ Three-year average.

${ }^{b}$ Animal units. Calculated using 1.0 units for cows and steers 3-4 years, 0.6 units for heifers and steers $1-2$ years, and 0.9 units for heifers and steers 2-3 years.

\section{MODEL EXPERIMENTATION AND SIMULATION}

\section{Nutritional factors in the dual-purpose system}

The results from our baseline model support the a priori hypothesis that nutritional factors represent major limitations to increased system productivity and profit. Adequate consumption of ME subject to NDF and DM intake consistently restricts increases in herd productivity and net margin; ME is a consistently binding constraint for all animal groups and model periods. Metabolizable protein, however, was binding only for lactating cows and not for all model periods. In addition, mobilization and repletion of adipose and protein tissue in lactating cows consistently form part of optimal LP solutions. The management of tissue dynamics for dual-purpose cows should thus receive greater emphasis than it has previously in assessing and formulating nutritional management strategies for dual-purpose herds.

\section{Assessing the impacts of resource and price changes}

We applied the LP model of dual-purpose production to answer resource and price policy questions, selecting three criteria to assess the impacts of restricting labor availability and the price changes brought about through government policy. Patterns of land use on dual-purpose farms, financial measures, and the sensitivity of the dual-purpose production system to changes in the producer milk price provide a cross-section of measured impacts that are potentially important to dual-purpose producers and government policy makers. 
As discussed previously, improved land management and productivity has the potential to increase milk and beef production while simultaneously easing pressures on the limited land base of Latin American countries. Farm profitability provides an indication of future supplies of milk and beef; higher profitability should result in increased production on existing farms, and the potential for supply by new entrants. Profitability also measures producer welfare (although this is less applicable in the case of absentee land owners) and indicates the impacts and effectiveness of government policy when input and output prices are controlled. Knowledge of the responsiveness of dual-purpose farms is potentially important to policy makers seeking to balance domestic production and imports of milk and beef.

\section{Land use patterns}

All LP model formulations included activities for land not used in the grazing rotation. These activities were analogous to slacks in the total land use constraints, and had zero objective function coefficients. Land use patterns for the four LP model formulations correspond to the six periods used to describe the 3-year cow replacement cycle.

All land for pasture production was used during the rainy season in the B, AF, and PPC model formulations; land was consistently in excess during the dry season and for the RL model formulation (Fig. 2). Compared to the baseline (which represents common management practice in Sur del Lago in 1988), the AF formulation predicted that more land

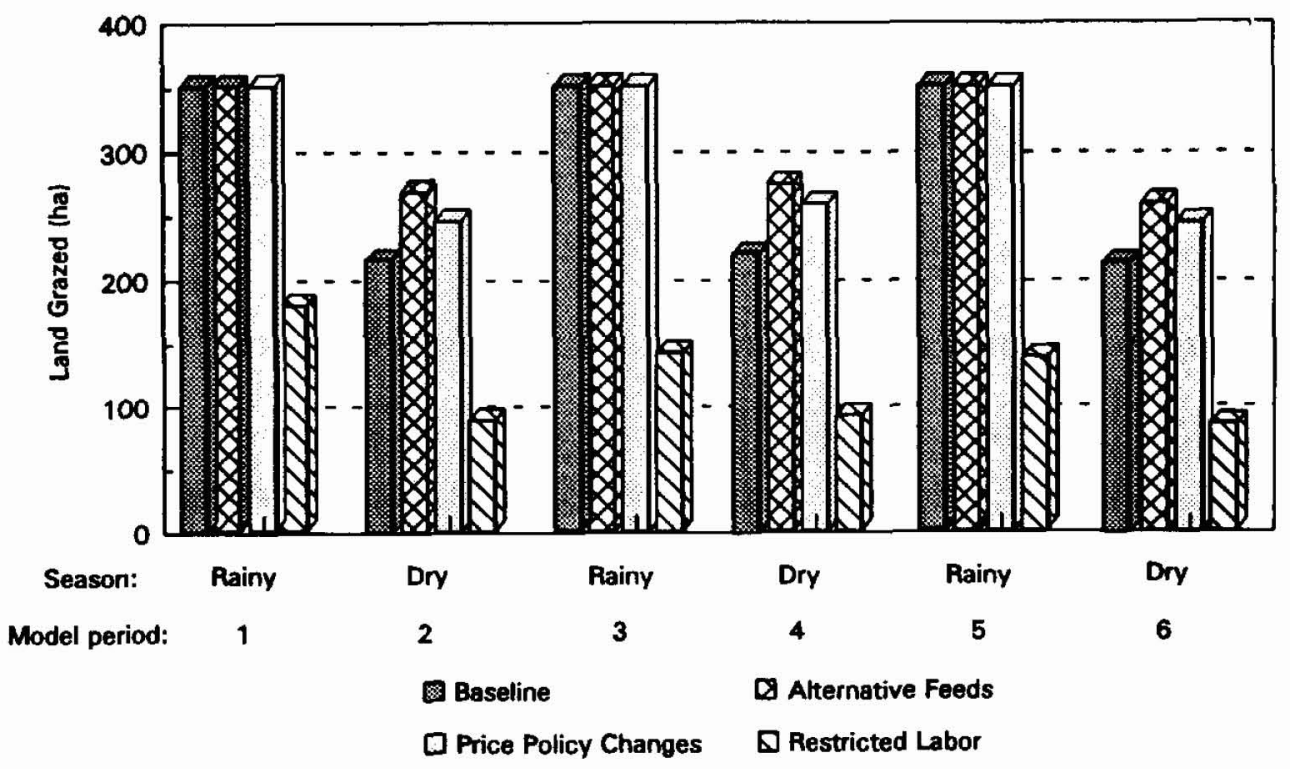

Fig. 2. Land use patterns predicted by the LP model. 
could be profitably grazed during the dry season. Thus, our models indicate that alternative feeds can permit more intensive dry-season use of land. Grazing an average of 267 ha during the dry season $(76 \cdot 3 \%$ of the total available) was optimal for the AF formulation, whereas slightly less dry-season grazing ( 250 ha, $71.3 \%$ ) was optimal for the PPC formulation.

The pattern of excess dry season land predicted by our models is the inverse of that more typically observed in the wet-dry tropics of Latin America, because fertilization (which occurs in the dry-season in the Sur del Lago) boosted yields of energy and protein from forage. In contrast to many other regions in Latin America, soil moisture seldom limits dry-season forage growth in the Sur del Lago, although soil moisture can be excessive during the rainy season. Thus, in contrast to other tropical areas, rainy season production of forage limited productivity of the land resource.

Restricting labor availability markedly decreased the use of the land resource; excess land of 49-76\% (171-265 ha) occurred in all model periods (Fig. 2). This implies that labor availability and turnover may limit the productivity of land on some dual-purpose farms. This result is consistent with anecdotal evidence presented by Holmann (1989) for this region of Venezuela concerning labor turnover. Relatively small differences in land use existed between the AF and PPC model formulations, indicating that the price changes had a relatively small effect on land use compared to the baseline AF scenario.

Although intuitively it may seem less profitable to graze only part of the complement of land in the dry season, interactions between grazing intensity and forage quality support our results. The greater productivity of fertilized forage during the dry season implies that more grazing pressure is necessary to maintain the energy and protein levels of the forage (which were fixed in our model). Because herd structure constraints dictated roughly equal animal inventories in all model periods, rainy season nutritional supplies ultimately limited herd size. Thus, the model predicts fewer animals than necessary to completely consume the more plentiful dry season forage nutrients. However, if all land were grazed in the dry season, forage quality and animal performance likely would be less than those we specified.

\section{Financial measures}

Herd net margin and revenues from milk and beef sales provide an indication of the relative incentives dual-purpose producers perceive under differing feeding strategies, resource availabilities, and prices. The AF model generates the largest herd net margin of models using 1987-88 prices (Table 7); herd net margin is $16 \%$ larger for the AF formulation than for the Baseline. Thus, a nutritional management strategy using 
TABLE 7

Financial Returns Predicted by LP Model Formulations

\begin{tabular}{|c|c|c|c|c|}
\hline \multirow[t]{2}{*}{ Financial measure } & \multicolumn{3}{|c|}{ LP model formulation } & \multirow{2}{*}{$\begin{array}{c}\text { Price } \\
\text { policy } \\
\text { changes }\end{array}$} \\
\hline & Baseline & $\begin{array}{l}\text { Alternative } \\
\quad \text { feeds }\end{array}$ & $\begin{array}{l}\text { Restricted } \\
\quad \text { labor }\end{array}$ & \\
\hline Variable costs, ${ }^{a} \mathrm{Bs}^{b} \times 10^{3}$ & 7299 & 7987 & 2380 & 12212 \\
\hline $\begin{array}{l}\text { Feed percent of } \\
\text { variable costs }\end{array}$ & 38.9 & $38 \cdot 1$ & $30 \cdot 0$ & $43 \cdot 8$ \\
\hline Revenues, ${ }^{a} \times 10^{3} \mathrm{Bs}^{b}$ & 18438 & 20932 & 7854 & 31014 \\
\hline \multicolumn{5}{|l|}{ Percent of revenues from: } \\
\hline Milk sales ${ }^{c}$ & $68 \cdot 2$ & $66 \cdot 3$ & $54 \cdot 4$ & $77 \cdot 6$ \\
\hline Animal sales ${ }^{c}$ & $31 \cdot 8$ & $33 \cdot 7$ & $45 \cdot 6$ & $22 \cdot 4$ \\
\hline Net margin, ${ }^{a} \times 10^{3} \mathrm{Bs}^{b}$ & 11139 & 12946 & 5474 & 18802 \\
\hline \multicolumn{5}{|l|}{ Net margin per cow } \\
\hline per year ${ }^{c}$ & 7072 & 7443 & 10251 & 11458 \\
\hline
\end{tabular}

${ }^{a}$ Three-year nominal total in undiscounted Bolívares predicted by LP model formulation.

${ }^{b}$ Bolívares, the Venezuelan currency. In 1987-88, 30 Bs equalled \$1 US. In 1989, 45 Bs equalled \$1 US.

'Average value for 3 years.

molasses and urea appears to increase farm profitability relative to feeding $2 \mathrm{~kg}$ of commercial concentrate per cow per day. The RL formulation generates dramatically reduced herd net margin relative to the AF formulation, emphasizing the importance of labor availability to the Sur del Lago dual-purpose system.

Comparisons of the AF and PPC model formulations assess the impacts of the 1989 price changes. Herd net margin increased by $45 \%$ under 1989 prices compared to $1987-88$ prices (represented by the AF model). Thus, the policy changes appear to provide additional incentives to dual-purpose producers relative to previous price policies. However, high inflation in Venezuela ( $87 \%$ in 1989) implies that the purchasing power of predicted increases in net margin may have declined rather than increased after the price changes were implemented.

Prices of most inputs increased by more than prices for milk and beef under the new price policies; this is especially true for feed inputs (Table 5). In part because the price of milk increased by more than the price of beef, our model predicts that dual-purpose producers would devote relatively more resources to milk production under the 1989 prices. Milk production and the percentage of revenues from milk are larger for the PPC model than for the AF model; the new price policies thus appear to provide an incentive for increased milk production. Increased feed costs as a percentage 
of variable costs-from $38 \%$ under the AF formulation to nearly $44 \%$ under the PPC scenario-also reflect higher feed prices and increased use of resources for milk production.

The relative incentives for milk and beef production, and the flexibility in use of resources on dual-purpose farms, are illustrated by the percentage of revenues from milk and beef in each of the four model formulations. For the RL scenario, revenues from milk and beef were much more nearly equal than for the AF scenario, a result driven by the relative labor intensity of dairy compared to beef production. The RL model indicates that dual-purpose producers would adjust to labor scarcity by increasing beef production, which is less labor intensive, and would simultaneously lower feed costs as a percentage of all costs. The increase in the price of milk relative to beef, simulated with the PPC model formulation, indicates that dual-purpose producers would increase milk revenues relative to beef revenues (Table 7), thereby maintaining higher total revenues and net margin than if the original milk-beef mix were maintained under the new prices. Thus, the model formulations predict producer behavior consistent with the changes in relative prices of milk and beef.

\section{Response to changes in producer milk price}

Ranges of optimality (the values of input and output prices for which a given model solution remains optimal) derived from an LP model are one measure of production system responsiveness. We examined ranges of optimality for milk prices during rainy and dry seasons for the four LP model formulations (Table 8). In the AF and PPC models, an increase as small as $0.03 \mathrm{Bs}$ in the milk price would induce a change in the optimal solution. Although the range of optimality alone does not

TABLE 8

Ranges of Optimality for Milk Price for LP Model Formulations, by Season

Season, product

Model formulation, ranges (Bs/unit)

\begin{tabular}{|c|c|c|c|c|c|c|c|c|}
\hline & \multicolumn{2}{|c|}{ Baseline } & \multicolumn{2}{|c|}{$\begin{array}{l}\text { Alternative } \\
\quad \text { Feeds }\end{array}$} & \multicolumn{2}{|c|}{$\begin{array}{l}\text { Restricted } \\
\text { Labor }\end{array}$} & \multicolumn{2}{|c|}{$\begin{array}{c}\text { Price Policy } \\
\text { Changes }\end{array}$} \\
\hline & Lower & Upper & Lower & Upper & Lower & Upper & Lower & Upper \\
\hline Rainy season, milk ${ }^{a}$ & 4.41 & $7 \cdot 30$ & 1.96 & 4.93 & $2 \cdot 36$ & 6.08 & 8.97 & 9.03 \\
\hline Dry season, milk ${ }^{a}$ & $3 \cdot 37$ & $12 \cdot 35$ & 1.74 & 4.93 & -2.99 & $8 \cdot 56$ & 8.91 & 9.08 \\
\hline
\end{tabular}

${ }^{a}$ Undiscounted Bolívares per liter of milk. Milk price in $1987-88$ was 4.90 Bs per liter; milk price in 1989 was 9.00 Bs per liter. 
indicate the magnitude of any production shift in response to a price change, it does indicate that the production system as modeled by the $\mathrm{AF}$ and PPC formulations is highly responsive to small price changes. Both the B and RL scenarios are less responsive to changes in milk prices, the former due primarily to rigidities implied by concentrate-only feeding, and the latter due to restrictions imposed on the system by limited labor availability. Milk price changes of 24 to $75 \%$ were required to produce a shift in optimal farm management. Thus, the $84 \%$ actual increase in milk price in 1989 would imply a change in optimal management, even with the restrictions on the amount of hired labor.

\section{CONCLUSIONS}

Results from our analysis indicate that alternatives to traditional nutritional management - especially the increased use of locally available feeds such as molasses and urea-appear to be profitable and nutritionally feasible. Moreover, the benefits of using locally available feeds are multi-faceted. Increased intensity of land use, permitted by improved nutritional management, may help slow increases in land area required for cattle production, decrease the use of imported feedgrains, and benefit consumers by increasing milk and beef production.

However, our results also show that the benefits of adopting alternatives to current nutritional management depend crucially on labor market factors, specifically, labor availability for milking and pasture management on dual-purpose farms. Limiting the availability of hired labor in our model-based on observed market outcomes in western Venezuela-dramatically reduced milk production, farm profitability, and the intensity of land use compared to models without restrictions on the availability of workers. Further research on labor turnover and retention in western Venezuela could help clarify the key labor market constraints.

Our stylized treatment of the changes in price policy that occurred from 1987 to 1989 indicated that a representative farm would increase milk production slightly and receive a larger percentage of total revenues from milk sales. However, there is a lack of empirical evidence on structural changes in the Venezuelan dairy sector after the wrenching price policy changes of the late $1980 \mathrm{~s}$. A follow-up study of farm management practices, location characteristics, and profitability would provide useful information to policy makers concerned with the responsiveness of the dual-purpose system to further policy changes.

The structure and technical coefficients of our LP model could readily be 
modified and (or) expanded to analyze other dual-purpose production systems in Latin America. Climatic conditions, as well as economic and policy environments, differ markedly among countries and within regions of Latin America. Thus, it is important to examine to what extent the results of this study apply to other production systems and policy environments.

Policy makers in Latin American agriculture often have identified increased domestic milk and beef production, increased rural employment, and protection of environmentally sensitive lands as policy goals. Our model results suggest that alternatives to traditional nutritional management strategies on dual-purpose farms could contribute to achieving those policy goals; these alternatives may permit more intensive land use, thus increasing production and farm profitability while reducing incentives for new land clearing.

\section{ACKNOWLEDGEMENTS}

The authors gratefully acknowledge the contributions of Danny G. Fox, Peter J. Van Soest, Jim O'Connor, Federico Holmann, Paul W. Townsend, Wendy Barrett, and June Ploss to developing the LP model of the dual-purpose cattle production system.

\section{REFERENCES}

Fox, D. G., Sniffen, C. J., O'Connor, J. D., Russell, J. B. \& Van Soest, P. J. (1992). A net carbohydrate and protein system for evaluating cattle diets: III. Cattle requirements and diet adequacy. Journal of Animal Science, 70, 3578-96.

Franco, M. A. (1987). Prototipo de unidad familiar, Carimagna, Colombia. Centro Internacional de Agricultura Tropical (CIAT), Cali, Colombia.

Gutierrez-Alemán, N., De Boer, A. J., Hart, R. D. \& Kehrberg, E. W. (1986). A bio-economic model of small-ruminant production in the semi-arid tropics of the northeast region of Brazil: Part 2 - Linear programming applications and results. Agricultural Systems, 19, 55-66.

Holmann, F. J. (1989). Economic evaluation of dairy and dual purpose production systems in Venezuela. PhD dissertation, Cornell University, Ithaca, New York.

Kearl, L. C. (1982). Nutrient requirements of ruminants in developing countries. Logan, Utah: International Feedstuffs Institute, Utah Agricultural Experiment Station, Utah State University.

McCarl, B. A. \& Apland, J. (1986). Validation of linear programming models. Southern Journal of Agricultural Economics, 18, 155-64.

Moe, P. W., Tyrrell, H. F. \& Flatt, W. P. (1971). Energetics of body tissue mobilization. Journal of Dairy Science, 54, 548-53.

National Research Council (1988). Nutrient Requirements of Dairy Cattle. 6th revised edn. National Academy Press, Washington, D.C.

Neidhardt, R., Plasse, D., Weniger, J. H., Verde, O., Beltran, J. \& Benavides, A. 
(1979). Milk yield of Brahman cows in a tropical beef production system. Journal of Animal Science, 48, 1-6.

Nicholson, C. F. (1990). An optimization model of dual purpose cattle production in the humid lowlands of Venezuela. MSc thesis, Cornell University, Ithaca, New York.

Nicholson, C. F., Blake, R. W., Urbina, C. I., Lee, D. R., Fox, D. G. \& van Soest, P. J. (in press). Economic comparison of nutritional management strategies for Venezuelan dual-purpose cattle systems. J. Animal. Science.

O'Connor, J. D., Sniffen, C. J. \& Fox, D. G. (1990). The Cornell Net Carbohydrate and Protein System for Evaluating Cattle Diets. Part II: A Computer Spreadsheet for Diet Evaluation. Ithaca, New York: Cornell University Agricultural Experiment Station, New York State College of Agriculture and Life Sciences. (SEARCH:AGRICULTURE Number 34).

Ramírez, A. (1987). Cómo calcular el costo de producción de un litro de leche? ASOGAL, 19, 3640.

Reid, R. L., Jung, G. A. \& Thayne, W. V. (1988). Relationships between nutritive quality and fiber components of cool and warm season forages: A retrospective study. Journal of Animal Science, 66, 1275-91.

Reyes, A. A., Blake, R. W., Shumway, C. R. \& Long, J. T. (1981). Multistage optimization for dairy production. Journal of Dairy Science, 64, 2003-16.

Russell, J. B., O'Connor, J. D., Fox, D. G., Van Soest, P. J. \& Sniffen, C. J. (1992). A net carbohydrate and protein system for evaluating cattle diets: I. Ruminal fermentation. Journal of Animal Science, 70, 3551-61.

Seré, C. \& de Vaccaro, L. (1985). Milk production from dual-purpose systems in tropical Latin America. In Milk Production in Developing Countries, ed. A. J. Smith. Centre for Tropical Veterinary Medicine, University of Edinburgh, Edinburgh, pp. 459-75.

Sniffen, C. J., O'Connor, J. D., Fox, D. G., Van Soest, P. J. \& Russell, J. B. (1992). A net carbohydrate and protein system for evaluating cattle diets: II. Carbohydrate and protein availability. Journal of Animal Science, 70, 3562-77.

Teitzel, J. K. (1991). Productive and stable pasture systems for cattle fattening in the humid tropics. 3. Development and use of a computer model to evaluate management options. Agricultural Systems, 36, 279-96.

Townsend, P. W., Blake, R. W., Holmann, F. J., Van Soest, P. J., Sniffen, C. J. \& Sisler, D. G. (1990). Low cost feeding strategies for dual purpose cattle in Venezuela. Journal of Dairy Science, 73, 792-803.

Van Soest, P. J. (1987). Nutritional Ecology of the Ruminant. Comstock Publishing, Ithaca, NY.

Williams, C. B., Oltenacu, P. A. \& Sniffen, C. J. (1989). Application of neutral detergent fiber in modeling feed intake, lactation response, and body weight changes in dairy cattle. Journal of Dairy Science, 72, 652-63. 


\section{APPENDIX 1}

\section{NUTRITIONAL AND HERD STRUCTURE CONSTRAINTS}

\section{Nutritional constraints}

Intake of metabolizable energy (ME) and metabolizable protein (MP) The LP model requires that animal requirements for ME and MP be satisfied by feed intake (and tissue mobilization for lactating cows) subject to constraints on intake of NDF and dry matter. Constraints for minimum required intake of $\mathrm{ME}$ are of the form:

$\left(M E R_{i t}\right)\left(A_{i t}\right)-\sum_{j}\left(F M E_{i j t}\right) F P_{i j t}-\sum_{k}\left(S U P M E_{i k t}\right)\left(S U P P_{i k t}\right) \pm T M R M E_{\text {cow.t }} \leq 0$

where $i=$ animal class, $j=$ forage type, $k=$ supplement type, $t=$ model period, cow $=$ stage of lactation (applies only to cows), $A=$ number of animals, $M E R=\mathrm{ME}$ requirement per period, $F M E=$ ME per unit forage per period, $F P=$ forage production per period, $S U P M E=$ ME per unit supplement feed, $S U P P=$ supplement feeds purchased per period, and $T M R M E$ indicates adipose tissue mobilized ( $(-)$ or repleted $(+)$. Constraints for intake of MP are defined analogously, with $M P R_{i t}$, for $M E R_{i t}, F M P_{i j t}$ for $F M E_{i j t}, S U P M P_{i k t}$ for $S U P M E_{i k t}$ and $T M R M P_{\text {cow.t }}$ for $T M R M E_{\text {cow. } t \text {. }}$

Intake of neutral detergent fiber (NDF) and dry matter (DM)

Maximum intake of NDF and DM are modeled with constraints of the form:

$$
-\left(N D F_{i t}\right)\left(A_{i t}\right)+\sum_{j}\left(F P N D F_{i j t}\right)\left(F P_{i j t}\right)+\sum_{k}\left(S U P N D F_{i k t}\right)\left(S U P P_{i k t}\right) \leq 0
$$

where $i, j, k, t, A, F P$, and $S U P P$ are defined as above, $N D F=\mathrm{NDF}$ intake limit per period, $F P N D F=$ NDF content of forage consumed per period, and $S U P N D F=$ NDF content of supplemental feeds consumed per period. Constraints for intake of dry matter are defined analogously, with $D M_{i t}$ for $N D F_{i t}, F P D M_{i j t}$ for $F P N D F_{i j t}$ and $S U P D M_{i k t}$, for $S U P N D F_{i k t}$.

Crude protein content of alternative feeds

Mixtures of molasses, urea, and cassava are constrained to $26.5 \%$ crude protein equivalent to avoid rumen nitrogen depletion; molasses-urea mixtures must have at least a 5:1 ratio of molasses to urea. Constraints are of the form:

$$
\begin{gathered}
-0.155 M O L_{i t}+2 \cdot 519 U_{R E A_{i t}}-0.085 C A S S_{i t}=0 \\
-5 U R E A_{i t}+M O L_{i t} \geq 0
\end{gathered}
$$

where $M O L=$ as-fed quantity of molasses per period, $U R E A=$ as-fed quantity of urea per period, and $C A S S=$ as-fed quantity of cassava per period. 
Tissue mobilization and repletion

Adipose and protein tissue mobilized during the first 90 days of lactation must be repleted by the next parturition; $50 \%$ of tissue must be repleted during lactation to maintain reproductive performance. Because the number of cows in each lactation stage is constant, the tissue dynamics can be modeled as if all tissue changes occurred in the concurrent period. Tissue mobilization and repletion constraints are of the form:

$$
\begin{gathered}
-(M E T)\left(C O W L L_{t}\right)+M E T L L_{t} \leq 0 \\
\left(M E T L L_{t}\right)(R F)(E L G / E L L)-M E T L G_{t} \leq 0 \\
\left(M E T L L_{t}\right)(E D G / E L L)-\left(M E T L G_{t}\right)(E D G / E L G)=0
\end{gathered}
$$

where $M E T=$ ME per cow available from adipose tissue mobilization, $C O W L L=$ number of cows 1-90 days in milk (i.e. cows in negative energy balance), $M E T L L=$ tissue mobilization for all $C O W L L$ per period, $R F$ is the percentage of mobilized tissue that must be repleted during lactation $(50 \%), E L L=\mathrm{ME}$ from tissue mobilization, $E L G=\mathrm{ME}$ required for tissue repletion in lactation, $E D G=\mathrm{ME}$ requirements for tissue repletion post-lactation, $M E T L G=$ adipose tissue repletion during lactation per period, and $M E T D G=$ adipose tissue repletion post-lactation. Analogous constraints were specified for protein tissue mobilization and repletion.

\section{Herd structure constraints}

Proportions of cows in three lactation stages

The proportion of cows in each stage of the 420-day calving interval is constant; constraints are of the form:

$$
\begin{aligned}
& C O W L L_{1}-\frac{M L L-(C M)(C M L L)(W E A N)}{M D G+(C M)(W E A N)}\left(C O W D G_{1}\right)=0 \\
& C O W L G_{1}-\frac{M L G-(C M)(C M L G)(W E A N)}{M D G+(C M)(W E A N)}\left(C O W D G_{1}\right)=0
\end{aligned}
$$

where $C O W L L, C O W L G$, and $C O W D G$ are the number of cows from 1-90 days in milk, 91-270 days in milk, and 271-420 days post-calving, respectively. $M L L, M L G$, and $M D G$ are the durations (in months) of each stage of lactation. $C M$ is calf mortality from birth to weaning (7.5\%), and $C M L L$ and $C M L G$ are the proportions of calf mortality occurring in each stage of lactation. $W E A N$ is calf weaning age ( 8 months).

\section{Calf numbers}

Calf numbers are assumed as a fixed proportion of cow numbers. The form of constraints used for female calves is:

$$
F C A_{\mathrm{t}}-(C C)(1-C M)(0 \cdot 5)\left(C O W L L_{t}+C O W L G_{t}+C O W D G_{t}\right)=0
$$


where $F C A=$ number of female calves, $C C=$ herd average calf crop per year $(71 \%), C M=$ calf mortality, and $C O W L L, C O W L G$, and $C O W D G$ are as previously defined. Analogous constraints were specified for male calves.

\section{Herd transfers}

The general form for herd transfer constraints is $A_{i, t+1}=A_{i, t}+$ Additions $_{t}-$ Subtractions. An example for the number of heifers 1-2 years of age would be:

$$
\begin{gathered}
H E 1_{t+1}=H E 1_{t}+F C A \text { maturing }_{t}-\text { Sales } F C A \text { maturing }_{t} \\
-H E 1_{t} \text { maturing to HE2 class } \\
- \text { Mortality in non-maturing } H E 1_{t}
\end{gathered}
$$

where $H E 1=$ number of heifers 1-2 years of age, $F C A=$ number of female calves, $H E 2=$ number of heifers 2-3 years of age. Analogous constraints were specified for calves, heifers, and steers.

Cows culled

Cows culled are related to total cow numbers in constraints of the form:

$$
C U L L C O W_{t}=(C R)\left(P E R L E N_{t} / 12\right)\left(C O W L L_{t}+C O W L G_{t}+C O W D G_{t}\right)
$$

where $C U L L C O W=$ number of cows culled per period, $C R=$ cull rate per year $(20 \%), P E R L E N=$ length of period in months (9 or 3$)$, and $C O W L L, C O W L G$, and COWDG are as previously defined.

Replacement heifers

The number of replacement heifers required to maintain herd size is equal to the number of cows culled in period $t$. This implies a relationship among total first-calf heifers, cull cows, and first-calf heifers sold of the form:

$$
\text { HE2 } \text { maturing }_{t}=\text { CULLCOW } W_{t}+S A L E H E 2_{t}
$$

where $H E 2$ and $C U L L C O W$ are as defined previously, and $S A L E H E 2=$ sales of heifers $2-3$ years of age per period.

Animal sales

Optimal animal sales are determined by the LP model. The general form of relationships governing sales of animal classes is:

Sales $A_{i t} \leq$ Maturing $A_{i t}-$ Mortality $A_{i t}$ 


\section{APPENDIX 2}

\section{ASSUMPTIONS, SOURCES, AND METHODS FOR SELECTED LP MODEL TECHNICAL COEFFICIENTS}

\begin{tabular}{|c|c|c|c|}
\hline Assumption category & Value & Units & Source, method \\
\hline \multicolumn{4}{|l|}{ Land area } \\
\hline Land area & 350 & ha & Holmann survey data; average of 22 dual-purpose farms \\
\hline \multicolumn{4}{|l|}{ Area in water-tolerant } \\
\hline species & 140 & ha & Holmann survey data; average of 22 dual-purpose farms \\
\hline \multicolumn{4}{|l|}{ Animal description ${ }^{a}$} \\
\hline Frame size & 3 & 1 to 9 scale & O'Conner et al. (1990); field observations \\
\hline Flesh code & 3 & 1 to 9 scale & O'Conner et al. (1990); field observations \\
\hline Milk production per cow & 2500 & $\mathrm{~kg}$ & Holmann survey data; CNCPS estimations \\
\hline Lactation length & 270 & Days & Holmann survey data; Stanton (unpublished data) \\
\hline Milk consumed by calf & 610 & $\mathrm{~kg}$ & CNCPS estimations \\
\hline Breed & Holstein-Zeb & - & Holmann survey data \\
\hline Grazing unit size & 1.65 & $\mathrm{ha} / \mathrm{AU}$ & Holmann survey data, average of 22 dual-purpose farms \\
\hline \multicolumn{4}{|l|}{ Adipose tissue } \\
\hline Maximum mobilization & 67 & $\mathrm{~kg}$ & CNCPS estimation for forage-concentrate diet \\
\hline Mobilization time frame & 90 & days & CNCPS estimation for forage-concentrate diet \\
\hline Nutritive value & $32 \cdot 7$ & MJ ME/kg & Moe et al. (1971) \\
\hline \multicolumn{4}{|l|}{ Repletion requirement } \\
\hline Lactating cow & $34 \cdot 0$ & $\mathrm{MJ} \mathrm{ME} / \mathrm{kg}$ & \multirow{2}{*}{$\begin{array}{l}\text { Derived from relationships of } \mathrm{NE}_{1} \text { values during lactation } \\
\text { in National Research Council (1988) }\end{array}$} \\
\hline Dry cow & 43.4 & $\mathrm{MJ} \mathrm{ME} / \mathrm{kg}$ & \\
\hline \multicolumn{4}{|l|}{ Protein tissue } \\
\hline Maximum mobilization & 23 & $\mathrm{~kg}$ & CNCPS estimation for forage-concentrate diet \\
\hline Mobilization time frame & 90 & Days & CNCPS estimation for forage-concentrate diet \\
\hline Nutritive value & 800 & $\mathrm{~g} / \mathrm{kg}$ & National Research Council (1988) \\
\hline \multicolumn{4}{|l|}{ Repletion requirement } \\
\hline Lactating cow & 1000 & $\mathrm{~g} / \mathrm{kg}$ & Derived from relationships of MP values during lactation \\
\hline Dry cow & 2000 & $\mathrm{~g} / \mathrm{kg}$ & in National Research Council (1988) \\
\hline \multicolumn{4}{|l|}{ Nutritional } \\
\hline NDF intake limit & $1 \cdot 3-1 \cdot 7$ & $\%$ of BW/day & $\begin{array}{l}\text { Max. NDF consumption derived from Reid et al. (1988); } \\
\text { NDF intake during lactation from Williams et al. (1989) }\end{array}$ \\
\hline DM intake limit & $2 \cdot 2-2 \cdot 9$ & $\%$ of BW/day & $\begin{array}{l}\text { CNCPS estimates on DM intake for diets commonly } \\
\text { fed on farms surveyed by Holmann }\end{array}$ \\
\hline \multicolumn{4}{|l|}{ Labor requirements } \\
\hline \multirow[t]{3}{*}{ Milking } & 0.05 & Workers/cow & All labor requirements for animals developed from \\
\hline & $0.009 \mathrm{~W}$ & Workers/calf, steer & Holmann survey data and Fernández (personal \\
\hline & 0.013 & Workers/heifer & communication) \\
\hline Managerial/seasonal & 0.01 & Workers/cow & \\
\hline Pasture maintenance & $6 \cdot 1$ & $\begin{array}{l}\text { Worker-days/ } \\
\text { ha-per year }\end{array}$ & Holmann survey data; Ramírez (1987) \\
\hline \multicolumn{4}{|l|}{$\begin{array}{l}\text { Chemicals for pasture } \\
\text { production }\end{array}$} \\
\hline Herbicide equivalent & $1 \cdot 1$ & $\mathrm{~kg} / \mathrm{ha}$-per year & Querales (personal communication); 2,4-D acid \\
\hline Fertilizer $^{b}$ phosphate & 200 & $\mathrm{~kg} / \mathrm{ha}$-per year & Holmann survey data, field trials \\
\hline \multicolumn{4}{|l|}{ Input costs } \\
\hline \multicolumn{4}{|l|}{ Animal health, } \\
\hline $\begin{array}{l}\text { Labor, milking } \\
\text { Labor, managerial/ }\end{array}$ & 24783 & Bs/year, 1987-88 & $\begin{array}{l}\text { Labor costs from Holmann survey data and Fernández } \\
\text { (personal communication) }\end{array}$ \\
\hline seasonal & $28409 \mathrm{~B}$ & Bs/year, 1987-88 & \\
\hline
\end{tabular}

a Animal descriptions used in the CNCPS model to estimate animal nutrient requirements are presented in Table 3.

${ }^{b}$ When fertilizer is applied. Forage production activities with and without fertilization are included in the LP model formulations. 